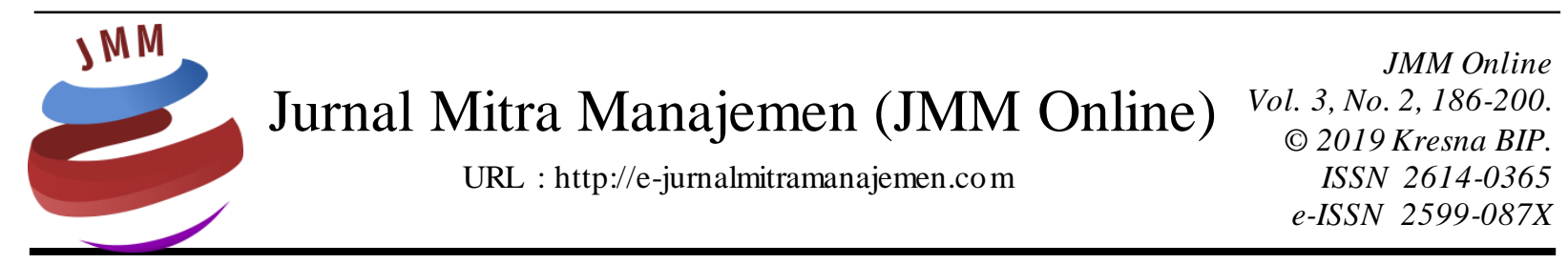

\title{
DAMPAK GAYA KEPEMIMPINAN TRANSFORMASIONAL, KEPEMIMPINAN TRANSAKSIONAL DAN ORIENTASI PEMBELAJARAN TERHADAP KREATIVITAS MAHASISWA DENGAN VARIABEL PEMEDIASI CREATIVE SELF-EFFICACY
}

\author{
Anne Rumondang Malau ${ }^{1)}$, Gloria Sianipar ${ }^{2)}$ \\ Universitas HKBP Nommensen
}

INFORMASI ARTIKEL

Dikirim : 08 Februari 2019

Revisi pertama : 20 Februari 2019

Diterima : 22 Februari 2019

Tersedia online : 04 Maret 2019

Kata Kunci: Kreativitas Mahasiswa, Creative Self-Efficacy, Kepemimpinan Transformasional, Kepemimpinan Transaksional, Orientasi Pembelajaran

Email : passeanne@gmail.com ${ }^{1)}$, sianipar.gloria28@gmail.com ${ }^{2)}$
ABSTRAK

Penelitian ini menguji dan menganalisa dampak dari gaya kepemimpinan transformasional, transaksional dan orientasi pembelajaran pada kreativitas mahasiswa dengan menguji peran mediasi creative self efficacy. Penelitian dilakukan pada 110 mahasiswa Fakultas Ekonomi Universitas HKBP Nommensen yang mana, dalam proses pembelajaran hasil akhir yang diharapkan adalah mahasiswa memiliki pola pikir yang kreatif yang nantinya dapat menghasilkan output yang inovatif. Pengumpulan data dilakukan dengan studi survei menggunakan kuesioner. Informasi terkait variabel independen, yaitu kreativitas mahasiswa dikumpulkan melalui dosen yang mengajar di kelas responden tersebut (mahasiswa), hal ini dilakukan supaya tidak terjadi bias dalam melakukan penilaian yang objektif terhadap variabel yang diamati. Pengujian hipotesis menggunakan Structural Equation Modelling (SEM) dengan bantuan LISREL. Model Pengukuran merupakan Confirmatory factor analysis untuk setiap variabel dan Model Struktu ral untuk melihat hubungan antar variabel yang diamati. Hasil analisis menunjukkan bahwa dosen yang memiliki gaya kepemimpinan transformasional dimediasi oleh creative self efficacy mahasiswa akan menunjukkan pengaruh positifdan signifikan terhadap kreativitas mahasiswa. 


\section{PENDAHULUAN \\ Latar Belakang}

Kreativitas dengan ide-ide baru dan berguna sangat penting untuk kelangsungan hidup dan daya saing organisasi (Amabile, 1988; Gong et al., 2009; Oldham dan Cumming, 1996). Penggunaan dan pengembangan ide kreatif yang memungkinkan organisasi untuk menyesuaikan diri, merespon peluang yang ada, sehingga dapat tumbuh dan bersaing (Nonaka dan Takeuchi, 1995) Kreativitas merupakan fungsi dari karakteristik pribadi dan karakteristik kontekstual individu di tempat ia berkinerja (Zhou dan Shalley, 2003; Shalley et al., 2004). Penelitian ini mengkaji dan menganalisa faktor-faktor yang membentuk kreativitas dalam diri individu.

Beberapa penelitian telah dilakukan untuk menyelidiki hal tersebut. Liu et al. (2003) menyatakan pemimpin menjadi peran yang sangat penting dalam pengelolaan yang efektif terhadap Individu. Ada dua gaya kepemimpinan yang sering dibicarakan beberapa tahun terakhir, yaitu kepemimpinan transformasional dan kepemimpinan transaksional. Kepemimpinan transformasional didefinisikan mempengaruhi pengikutnya dengan memperluas dan meningkatkan tujuan pengikut melebihi harapan (Dvir et al., 2002). Kepemimpinan transaksional didasarkan pada hubungan pertukaran yang mana pemimpin menjelaskan apa yang diharapkan dari pengikutnya.

Penelitian tentang bagaimana kepemimpinan mempengaruhi kreativitas individu masih belum konsisten dan konklusif (Gong et al. , 2009; Malau, 2012). Secara konseptual kepemimpinan transaksional di prediksi dapat mempengaruhi kreativitas individu ketika ditetapkan sebuah pengaturan tujuan kreativitas. Faktor lain yang mempengaruhi kreativitas adalah orientasi pembelajaran (Gong et al., 2009) Orientasi pembelajaran didefinisikan sebagai perhatian dan dedikasi untuk mengembangkan kompetensi individu. Suatu kondisi dibutuhkan untuk menjelaskan bagaimana suatu pengaruh terjadi dibeberapa penelitian dan di penelitian yang lain tidak dan memahami temuan atau hasil yang belum konsisten dan konklusif . Barron dan Kenny (1986) menyebutkan mekanisme psikologi menjadi salah satu fenomena atau isu yang diangkat untuk melihat pengaruh tersebut dari domain psikologi dan sosial. Creative self efficacy menjadi salah satu variabel yang diduga menjadi mekanisme psikologi yang menjelaskan pengaruh kepemimpinan transformasional dan transaksional pada kreativitas Individu. Penelitian yang melibatkan mahasiswa sebagai responden dipertimbangkan akan mengungkapkan pengaruh gaya kepemimpinan dan orientasi pembelajaran pada kreativitas individu.

\section{Rumusan Masalah} berikut:

Beberapa masalah yang dapat dirumuskan pada penelitian ini adalah sebagai

1. Apakah gaya kepemimpinan transformasional berpengaruh pada kreativitas mahasiswa?

2. Apakah gaya kepemimpinan transaksional berpengaruh pada kreativitas mahasiswa?

3. Apakah orientasi pembelajaran berpengaruh pada kreativitas mahasiswa?

4. Apakah gaya kepemimpinan transformasional dan transaksional serta orientasi pembelajaran berpengaruh pada kreativitas mahasiswa dengan variabel pemediasi creative self efficacy 


\section{Tujuan Penelitian}

Adapun tujuan yang ingin dicapai pada penelitian ini adalah sebagai berikut: Untuk mengetahui dampak dari gaya kepemimpinan transformasional dan transaksional serta orientasi pembelajaran pada kreativitas mahasiswa dengan variabel pemediasi creative self-efficacy.

\section{KAJIAN PUSTAKA}

\section{Kreativitas Mahasiswa}

Kreativitas merupakan suatu sumber daya bagi organisasi untuk bersaing dan mencapai keunggulan kompetitif. Individu yang memiliki kreativitas akan menghasilkan ide-ide yang baru, dan berguna tentang produk, praktik, pelayanan atau prosedur organisasi (Shalley et al., 2004). Kreativitas berbeda dengan inovasi. Kreativitas merupakan penciptaan dan pengembangan ide baru dan berguna, sedangkan inovasi merupakan hasil implementasi dari ide-ide baru tersebut (Amabile et al., 1996). Kreativitas mahasiswa didefinisikan sebagai pengembangan ide-ide tentang produk, praktek, layanan atau prosedur yang adalah baru, berguna secara potensial bagi organisasi, ide-ide kreatif dapat dihasilkan seseorang dalam pekerjaan apapun dan pada setiap tingkat organisasi (Zhou dan Shalley, 2003; Shalley et al., 2000). Kreativitas merupakan fungsi dari karakteristik pribadi dan karakteristik konteks di tempat ia berkinerja (Oldham dan Cummings, 1996). Karakteristik pribadi meliputi kepribadian dan dimensi gaya kognitif. Karakteristik kontekstual meliputi kompleksitas pekerjaan, hubungan dengan supervisor, penghargaan dan evaluasi (Shalley et al., 2004). Melalui karakteristik pribadi dan kontekstual tersebut mahasiswa akan membentuk kreativitas ditengah tugas pendidikan. Selanjutnya akan dikembangkan bagaimana faktor-faktor yang membentuk kreativitas berdasarkan pengembangan kajian pustaka.

\section{Kepemimpinan Transformasional}

Kepemimpinan transformasional merupakan kepemimpinan yang mempengaruhi pengikutnya dengan memperluas dan meningkatkan tujuan bawahan dan menyediakan mereka kepercayaan untuk berkinerja melampui harapan. Menurut Bass (1985), kepemimpinan transformasional mengambarkan sebuah perilaku pemimpin yang memiliki empat karakteristik, Pertama, yaitu stimulasi intelektual Dosen transformasional menggunakan dorongan intelektual untuk mendorong kreativitas mahasiswa, berperan kreatif dengan mengambil pendekatan baru untuk menangani masalah. Kedua pertimbangan individual, Dosen transformasional fokus pada pengembangan individu, melibatkan perhatian, menunjukkan empati, dan penghargaan serta mendukung ide mahasiswa. Ketiga, karisma atau pengaruh ideal. Dosen transformasional memiliki karisma dan pribadi yang inspirasional. Dosen sangat dikagumi, dihormati dan dipercayai. Keempat, motivasi inspirasional. Dosen transformasional memiliki motivasi yang inspirasional mendorong mahasiswa untuk memiliki sebuah visi, memberikan pandangan mengenai masa depan yang optimis dan dapat dicapai. Sehingga dapat dipahami keempat karakteristik kepemimpinan transformasional merupakan faktor yang menghasilkan kreativitas.

H1: Gaya Kepemimpinan transformasional berpengaruh positif dan signifikan pada kreativitas mahasiswa 


\section{Kepemimpinan Transaksional}

Menurut Burns (dalam Pieterse et al., 2010), kepemimpinan transaksional merupakan hubungan yang mempertukarkan jabatan atau tugas.. Kepemimpinan transaksional berfokus pada pengaturan tujuan (setting goal) melalui karakteristik contingent reward dan management by exception (Bass et al., 2003). Melalui karakteristik contingent reward, Dosen akan memberikan penghargaan kepada mahasiswa apabila tugas dapat diselesaikan dengan baik. Bentuk penghargaan berupa nilai bonus atau pujian yang memotivasi mahasiswa lebih kreatif. Melalui karakteristik yang kedua, yaitu management by exception, Dosen yang transaksional menekankan fungsi manajemen sebagai pengawasan. Dosen menjelaskan standar kerja (kontrak perkuliahan) agar penyimpangan tidak terjadi. Management by exception dalam bentuk pasif melakukan intervensi melalui kritik dan koreksi setelah terjadinya kesalahan. Dapat disimpulkan, pemimpin yang memiliki gaya kepemimpinan transaksional melakukan pengaturan tujuan dan menetapkan suatu tujuan kreativitas dan memberikan penghargaan dan pengawasan, sehingga kreativitas individu yang mengikutinya dapat dicapai (Shalley, 1991; Eisenberger dan Rhoades, 2001; Gong et al., 2009).

H2: Gaya Kepemimpinan Transaksional berpengaruh positif dan signifikan terhadap kreativitas mahasiswa.

\section{Orientasi Pembelajaran}

Ada dua karakteristik orientasi individu dalam menciptakan kerangka kerja yang mereka tafsirkan dan bereaksi terhadap suatu peristiwa. Fenomena orientasi tersebut dapat dijelaskan dengan konseptualisasi tujuan. Pertama, yaitu tujuan kinerja (perfomance goal), individu berfokus pada penilaian yang menguntungkan akan kompetensi mereka. Kedua, tujuan pembelajaran (learning goal), individu berfokus pada peningkatan kompetensi mereka. Tujuan yang berbeda mendorong respon pola perilaku individu yang berbeda. Menurut Ghafoor etal. (2011), individu dengan tujuan pembelajaran memiliki orientasi yang lebih besar untuk meningkatkan pengetahuan dan belajar tentang cara dan hal yang baru, sementara individu dengan tujuan kinerja lebih berorientasi hanya untuk menunjukkan kemampuan kepada orang lain dengan melakukannya dengan baik. Orientasi pembelajaran disebut sebagai pola penguasaan orientasi yang merupakan pengakuan individu bahwa kompetensi yang dimiliki individu dapat dikembangkan melalui pencapaian penguasaan ketrampilan, pengetahuan dan situasi yang baru (Elliot dan Church, 1997). Ketika individu diberikan tugas dan tantangan dengan kompleksitas pekerjaan yang tinggi, memerlukan tingkat pengetahuan, ketrampilan dan situasi baru, sehingga individu akan termotivasi dan merasa yakin mampu menyelesaikan tugas dan tujuan tersebut dengan baik dan dengan cara yang kreatif. Maka dapat disimpulkan bahwa orientasi pembelajaran merupakan kondisi yang tepat bagi individu untuk memperoleh dan meningkatkan pengetahuan dan kompetensi diri, sehingga menghasilkan kreativitas individu dalam melakukan kegiatan.

H3: Orientasi Pembelajaran berpengaruh positif dan signifikan pada kreativitas mahasiswa. 


\section{Creative Self Efficacy Sebagai Variabel Mediasi}

Creative self-efficacy didefinisikan sebagai keyakinan seseorang memiliki kemampuan untuk memproduksi hasil yang kreatif. Bandura (1977) juga menyebutkan ada empat sumber penilaian keyakinan individu yang dapat mempengaruhi creative self-efficacy, yaitu:Pertama, Vicarious Learning, merupakan suatu pembelajaran observasional dari pengalaman keberhasilan yang ditunjukkan oleh orang lain. Kedua, Verbal Persuasion. Orang yang mendapat persuasi secara verbal maka mereka memiliki kemampuan untuk menyelesaikan tugas-tugas yang diberikan. Ketiga, Enactive Mastery. Pengalaman masa lalu akan mengerahkan seluruh kemampuannya untuk meraih keberhasilan. Umpan balik individu yang positif akan meningkatkan kepercayaan diri individu. Keempat, Physiological arousal.. Dalam menilai kemampuannya seseorang dipengaruhi oleh informasi tentang keadaan fisiknya untuk menghadapi situasi tertentu dengan memperhatikan keadaan fisiologisnya. Dengan demikian, dapat disimpulkan bahwa sumber-sumber yang mempengaruhi creative selfefficacy tersebut dapat mempengaruhi gaya kepemimpinan transformasional dan transaksional serta orientasi pembelajaran menghasilkan kreativitas karyawan di tempat kerja

H4a: Creative self efficacy memediasi pengaruh positif kepemimpinan transformasional pada kreativitas mahasiswa.

H4b: Creative self efficacy memediasi pengaruh positif kepemimpinan transaksional pada kreativitas mahasiswa.

H4c: Creative self efficacy memediasi pengaruh positif kepemimpinan transaksional pada kreativitas mahasiswa.

\section{Kerangka Penelitian}

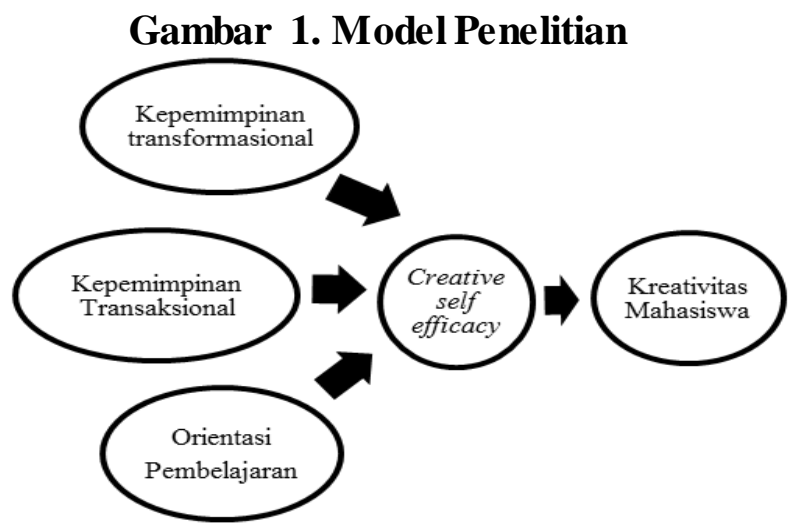

\section{METODE PENELITIAN}

Penelitian ini menggunakan pendekatan kuantitatif dengan confirmatory study menggunakan metode survei. Populasi dalam penelitian ini adalah Mahasiswa Fakultas Ekonomi Universitas HKBP Nommensen. Industri pendidikan dipilih karena Universitas merupakan salah satu pelaku pendidikan yang sangat mendukung terciptanya kreativitas individu Metode penggambilan sampel yang digunakan dalam penelitian ini adalah purposive sampling dengan kriteria yang harus dipenuhi oleh setiap sampel yaitu, individu yang menjadi sampel adalah mahasiswa yang mengambil 
mata kuliah Kewirausahaan. Responden penelitian berjumlah 100 orang. Penelitian ini dilaksanakan pada bulan April sampai dengan Oktober 2018. Metode analisis data meliputi uji validitas dan realibilitas dan pengujian hipotesis. Metode pengujian validitas, realibilitas dan hipotesis yang digunakan dalam penelitian ini adalah Structural Equation Modelling (SEM) dengan bantuan software LISREL 8.7. Variabel dalam penelitian ini terdiri dari 3 variabel laten yaitu, kepemimpinan transformasional, transaksional dan orientasi pembelajaran serta creative self efficacy sebagai variabel independen, kreativitas mahasiswa sebagai variabel dependen. Definisi operasional untuk variabel-variabel tersebut diuraikan sebagai berikut:

\section{Tabel 1. Definisi Operasional}

\begin{tabular}{|l|l|}
\hline \multicolumn{1}{|c|}{ Definisi Ope rasional } & \multicolumn{1}{|c|}{ Item Pertanyaan/Pe rnyataan } \\
\hline $\begin{array}{l}\text { Kepemimpinan transformasional didefinisikan } \\
\text { sebagai persepsi mahasiswa terhadap perilaku } \\
\begin{array}{l}\text { Dosen, yang mana mahasiswa percaya, bangga, } \\
\text { loyal dan hormat serta mahasiswa dimotivasi } \\
\text { untuk berbuat melebihi apa yang diharapkan. }\end{array}\end{array}$ & $\begin{array}{l}\text { Menggunakan 20 Multifactor } \\
\text { Leadership Questionaire Form } 5 X \\
\text { yang dikembangkan oleh Bass dan } \\
\text { Avolio (1995). }\end{array}$ \\
\hline $\begin{array}{l}\text { Kepemimpinan transaksional didefinisikan } \\
\text { sebagai persepsi mahasiswa terhadap perilaku } \\
\text { dosen dalam mengarahkan mahasiswa } \\
\text { mengerjakan tugas sesuai standar yang telah } \\
\text { ditetapkan. }\end{array}$ & $\begin{array}{l}\text { Menggunakan 8 Multifactor } \\
\text { Leadership Questionaire Form } 5 X \\
\text { yang dikembangkan oleh Bass dan } \\
\text { Avolio (1995). }\end{array}$ \\
\hline $\begin{array}{l}\text { Orientasi pembelajaran didefinisikan sebagai } \\
\text { pengakuan individu bahwa kompetensi yang } \\
\text { dimiliki dapat dikembangkan melalui } \\
\text { penguasaan ketrampilan, pengetahuan dan situasi } \\
\text { yang baru. }\end{array}$ & $\begin{array}{l}\text { Menggunakan 6 butir pernyataan dari } \\
\text { Elliot dan Church (1997), }\end{array}$ \\
\hline $\begin{array}{l}\text { Dalam penelitian ini variabel creative self- } \\
\text { efficacy didefinisikan sebagai pendapat } \\
\text { keyakinan individu bahwa mereka mampu untuk } \\
\text { memproduksi hasil yang kreatif.), }\end{array}$ & $\begin{array}{l}\text { Menggunakan dan mengadopso 6 butir } \\
\text { pernyataan } \text { creative self-efficacy dari } \\
\text { Tierney dan Farmer (2002) dan Riggs } \\
\text { et al. (1994) (Tang dan Chang, 2010) }\end{array}$ \\
\hline $\begin{array}{l}\text { Kreativitas mahasiswa didefinisikan sebagai } \\
\text { persepsi dosen terkait dengan ide } \\
\text { pengembangan tugas, praktik, dan pekerjaan } \\
\text { yang baru atau asli dan bermanfaat yang } \\
\text { dihasilkan oleh mahasiswa }\end{array}$ & $\begin{array}{l}\text { menggunakan 3 butir pernyataan yang } \\
\text { dikembangkan dari pengukuran } \\
\text { kreativitas karyawan Gong } \text { et al. } \\
\text { (2009) dan 3 butir pernyataan dari } \\
\text { Oldham dan Cummings (1996), }\end{array}$ \\
\hline
\end{tabular}

Sumber : Malau (2012)

\section{HASIL PENELITIAN DAN PEMBAHASAN}

\section{Hasil Penelitian}

\section{Evaluasi Uji Asumsi}

a. Evaluasi Kecukupan Sampel

Rule of thumb berdasarkan teknik Maximum Likelihood Estimation, jumlah minimum sampel yang direkomendasikan adalah berjumlah 100-400 atau lima kali parameter yang diestimasi (Hair et al., 2006). Jumlah sampel yang terkumpul dan dapat diolah dalam penelitian ini berjumlah 100 sampel, sehingga untuk kecukupan sampel memenuhi jumlah sampel minimum yang direkomendasikan. 
b. Evaluasi Normalitas Data

Asumsi paling mendasar dalam analisi multivariat adalah normalitas. Uji normalitas dalam penelitian ini dilakukan dengan menggunakan bantuan softwareLISREL 8.7. Hasil dari uji normalitas mengindikasikan bahwa data secara keseluruhan terdistribusi normal, baik secara univariat dan multivariat yang ditunjukkan dari $P$ Value dari Skewness dan Kurtosis> 0,05.

\section{Pengujian Model Pengukuran}

1. Konstruk Gaya Kepemimpinan Transformasional dan Transaksional Model pengukuran menggunakan uji face validity dan content validity, yang dilakukan untuk menguji keterkaitan teori antara item pertanyaan yang diajukan. Kepemimpinan Transformasional diukur dengan 20 item pernyataan Multifactor Leadership Questionaire $(M L Q)$ yang dikembangkan oleh Bass dan Avolio. Item-item tersebut telah teruji mampu mewakili konstruk kepemimpinan transformasional pada penelitian sebelumnya Kepemimpinan Transformasional diukur dengan 8 item pernyataan MLQ.(e.g Avolio et al., 1999; Shin dan Zhou, 2003; Gong et al., 2009; Malau, 2012).

2. Konstruk Orientasi Pembelajaran Model Pengukuran pada konstruk orientasi pembelajaran menggunakan first order confirmatory analysis. Evaluasi model pengukuran konstruk orientasi pembelajaran menunjukkan semua indikator konstruk memiliki faktor loading $>0,50$ dan semua indikator dinyatakan valid. Nilai Construct realibility $>0,70$ yaitu 0,72 maka semua indikator dinyaatakan reliabel.Uji kesesuaian model konstruk orientasi pembelajaran menunjukkan nilai $X^{2-}$ Chi Square (30,81, P: 0,00), GFI $(0,91)$ serta AIC dan CAIC dinyatakan sesuai (fit).

3. Model Pengukuran Konstruk Creative Self Efficacy. Evaluasi dilakukan terhadap output untuk melihat validitas dan reliabilitas indikator dan uji kesesuaian model. Hasil menunjukkan semua indikator dinyatakan valid dan reliabel dilihat dari nilai standardized loading factor $>0,50$ dan nilai construct realibility $>0,70$. Uji kesesuaian model (Goodness of fit) $X^{2-}$ Chi Square(22.92 ( $\left.\mathrm{P}=0.00\right)$, GFI $(0,92)$, NFI (0,90), CFI $(0,91)$ dan AIC serta CAIC dinyatakan sesuai (fit)

4. Model Pengukuran Konstruk Kreativitas Mahasiswa. Evaluasi dilakukan terhadap output untuk melihat validitas dan reliabilitas indikator dan uji kesesuaian model. Hasil menunjukkan semua indikator dinyatakan valid dan reliabel dilihat dari nilai standardized loading factor $>0,50$ dan nilai construct realibility $>0,70$. Uji kesesuaian model (Goodness of fit) menunjukkan nilai $\mathrm{X}^{2}$-chi square $(4,64=\mathrm{P}: 0,031)$, GFI $(0,99)$, NFI $(0,99)$, CFI $(1,00)$ dan AIC serta AIC dinyatakan Fit.

\section{Pengujian Model Struktural}

Setelah model pengukuran dinyatakan fit, dilakukan pengujian terhadap model struktural dengan menambahkan model pengukuran yang telah fit ke dalam model struktural. Pada tahap ini dilakukan evaluasi terhadap pengujian kesesuaian model berdasarkan beberapa kriteria uji kesesuaian model yang sama dengan kriteria uji kesesuaian model pada model pengukuran. Gambar 2 dan tabel 2 menyajikan output diagram alur model struktural dan uji kesesuaian model struktural 
Tabel 2. Evaluasi Uji Kesesuaian Model Struktural

\begin{tabular}{|l|l|l|l|}
\hline $\begin{array}{c}\text { Uji Kesesuaian } \\
\text { Model }\end{array}$ & \multicolumn{1}{c|}{ Cut-off Value } & \multicolumn{1}{c|}{ Hasil } & Keterangan \\
\hline$X^{2-}$ Chi Square & Rendah $(\mathrm{P}>0.05)$ & $544.95(\mathrm{P}=0.067)$ & Fit \\
\hline GFI & $\geq 0.90$ & 0.84 & Marginal Fit \\
\hline RMSEA & $\leq 0.08$ & 0.032 & Fit \\
\hline$A G F I$ & $\geq 0.90$ & 0.80 & Marginal Fit \\
\hline NFI & $\geq 0.90$ & 0.91 & Fit \\
\hline NNFI & $\geq 0.90$ & 0.98 & Fit \\
\hline$C F I$ & $\geq 0.90$ & 0.98 & Fit \\
\hline
\end{tabular}

Lanjutan Tabel 2. Evaluasi Uji Kesesuaian Model Struktural

\begin{tabular}{|l|l|l|l|}
\hline \multicolumn{1}{|c|}{$\begin{array}{c}\text { Uji Kesesuaian } \\
\text { Model }\end{array}$} & \multicolumn{1}{|c|}{ Cut-off Value } & \multicolumn{1}{|c|}{ Hasil } & Keterangan \\
\hline IFI & $\geq 0.90$ & 0.98 & Fit \\
\hline AIC & $\begin{array}{l}\text { Nilai yang lebih kecil } \\
\text { dari independence dan }\end{array}$ & $\begin{array}{l}\mathrm{M}^{*}=734.95 \\
\mathrm{~S}^{* *}=1122.00\end{array}$ & Fit \\
& $\begin{array}{l}\text { lebih dekat ke saturated } \\
\text { model }\end{array}$ & $\mathrm{I}^{* * *}=6839.27$ & Fit \\
\hline CAIC & $\begin{array}{l}\text { Nilai yang lebih kecil } \\
\text { dari independence dan } \\
\text { lebih dekat ke saturated } \\
\text { model }\end{array}$ & $\begin{array}{l}\mathrm{M}^{*}=1127.86 \\
\mathrm{~S}^{* * *}=3442.18\end{array}$ & \\
\hline
\end{tabular}

Sumber : Hasil Penelitian, diolah (2018)

Gambar 2. Diagram Alur Model Struktural

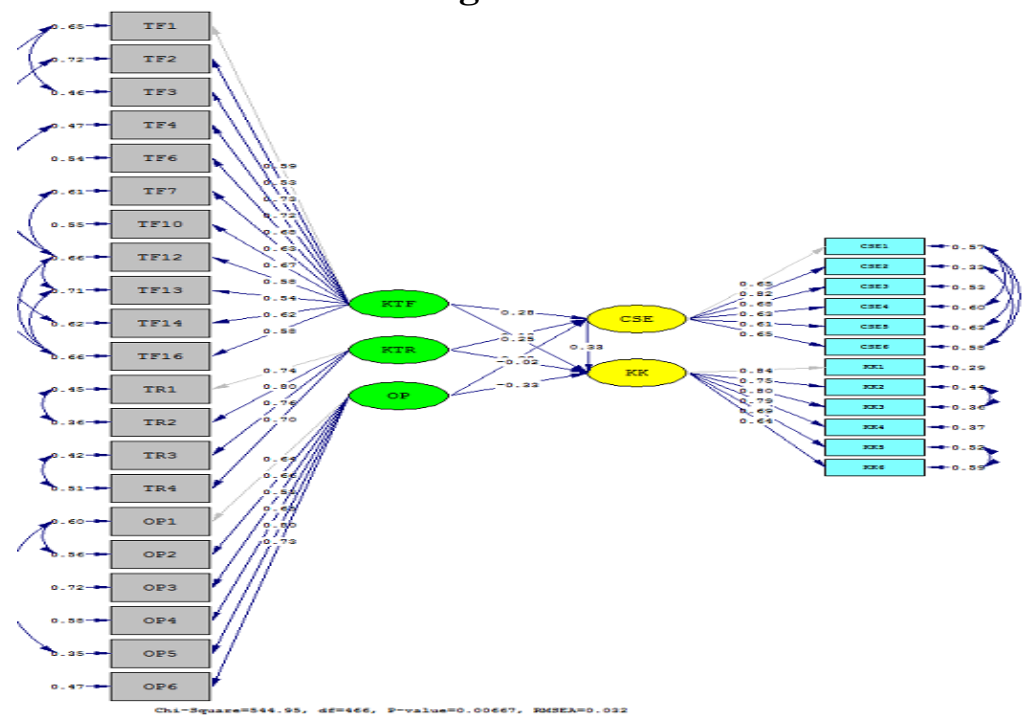

Berdasarkan evaluasi terhadap uji kesesuaian model structural secara keseluruhan model struktural sudah dapat dikatakan fit. Hair et al. (2006) menyatakan bahwa menggunakan tiga atau empat indeks kesesuaian memberikan bukti yang memadai suatu kesesuaian model. 


\section{Analisis Hubungan Kausalitas}

Setelah kriteria uji kesesuaian terpenuhi atas model struktural yang diestimasi, maka dilanjutkan dengan analisis terhadap hubungan-hubungan model struktural. Berdasarkan analisis terhadap model struktural secara keseluruhan dalam output LISREL, diperoleh persamaan struktural sebagai berikut:

$$
\begin{aligned}
& \mathrm{SE}=0.30 * \mathrm{KTF}+0.085 * \mathrm{KTR}+0.33 * \mathrm{OR}, \text { Errorvar. }=0.15, \mathrm{R}^{2}=0.31 \\
& \begin{array}{llll}
(0.13) & (0.084) \quad(0.13) \quad(0.037)
\end{array} \\
& \begin{array}{llll}
2.33 & 1.01 & 2.57 & 4.17
\end{array} \\
& \mathrm{KM}=0.43 * \mathrm{CSE}+0.35 * \mathrm{KTF}-0.024 * \mathrm{KTR}-0.49 * \mathrm{OP}, \text { Errorvar. }=0.31, \mathrm{R}^{2}=0.16 \\
& \begin{array}{lllll}
(0.15) & (0.18) & (0.11) & (0.18) & (0.051)
\end{array} \\
& \begin{array}{lllll}
2.91 & 1.99 & -0.21 & -2.73 & 6.16
\end{array} \\
& \mathrm{SE}=0.30 * \mathrm{KTF}+0.085 * \mathrm{KTR}+0.33 * \mathrm{OR}, \text { Errorvar. }=0.15, \mathrm{R}^{2}=0.31 \\
& \begin{array}{lll}
(0.13) \quad(0.084) \quad(0.13)
\end{array} \\
& 2.33 \quad 1.01 \quad 2.57 \\
& \mathrm{KM}=0.48 * \mathrm{KTF}+0.013 * \mathrm{KTR}-0.34 * \mathrm{OP} \text {, Errorvar. }=0.34, \mathrm{R}^{2}=0.083 \\
& \begin{array}{lll}
(0.18) \quad(0.12) \quad(0.17)
\end{array} \\
& 2.68 \quad 0.11 \quad-2.04
\end{aligned}
$$

(Keterangan: $\quad$ KTF=Kepemimpinan $\quad$ Transformasional $\quad ; K T R=$ Kepemimpinan Transaksional;OR=Orientasi Pembelajaran; SE= Creative Self Efficacy; $K M=$ Kreativitas Mahasiswa) Evaluasi dilakukan terhadap persamaan model struktural mencakup t-value dari koefisien estimasi > 1.96 menunjukkan signifikansi. Tabel 3 menyajikan nilai koefisien dan t-value hasil analisa model struktural yang digunakan juga untuk melihat pengujian hipotesis.

Tabel 3. Nilai Koefisien dant-value

\begin{tabular}{|l|l|l|l|l|}
\hline No & \multicolumn{1}{|c|}{ Path } & Koefisien & t-value & \multicolumn{1}{|c|}{ Kesimpulan } \\
\hline 1 & Creative Self Efficacy $\leftarrow$ & & & \\
& Kepemimpinan Transformasional & 0.30 & 2.33 & Signifikan \\
& Kepemimpinan Transaksional & 0.085 & 1.01 & Tidak signifikan \\
& Orientasi Pembelajaran & 0.33 & 2.57 & Signifikan \\
\hline 2 & Kreativitas Mahasiswa $\leftarrow$ & & & \\
& Kepemimpinan Transformasional & 0.48 & 2.68 & Signifikan \\
& Kepemimpinan Transaksional & 0.013 & 0.11 & Tidak Signifikan \\
& Orientasi Pembelajaran & -0.34 & -2.04 & Signifikan \\
\hline 3 & Kreativitas Mahasiswa $\leftarrow$ & & & \\
& Kepemimpinan Transformasional & 0.35 & 1.99 & Signifikan \\
& Kepemimpinan Transaksional & -0.024 & -0.21 & Tidak signifikan \\
& Orientasi Pembelajaran & -0.49 & -2.73 & Signifikan \\
& Creative self efficacy & 0.43 & 2.91 & Signifikan \\
\hline
\end{tabular}

Sumber :Data Diolah (2018)

Dari persamaan struktural juga diketahui bahwa masing-masing konstruk kepemimpinan transformasional, kepemimpinan transaksional dan orientasi pembelajaran mampu menjelaskan konstruk kreativitas mahasiswa sebesar 8,3\% $\left(\mathrm{R}^{2}=\right.$ 0.083). Masing-masing konstruk kepemimpinan transformasional, kepemimpinan transaksional dan orientasi pembelajaran mampu menjelaskan konstruk creative self efficacy sebesar $16 \%\left(\mathrm{R}^{2}=0.16\right)$. 


\section{Pembahasan}

Dalam pengujian hipotesis satu sampai dengan enam, peneliti melakukan evaluasi dengan tiga langkah yaitu, langkah pertama dilakukan evaluasi persamaan struktural kepemimpinan transformasional, kepemimpinan transaksional dan orientasi pembelajaran pada creative self efficacy, selanjutnya langkah kedua, mengevaluasi persamaan struktural kepemimpinan transformasional, kepemimpinan transaksional dan orientasi pembelajaran pada kreativitas mahasiswa, dan langkah yang ketiga, mengevaluasi persamaan struktural kepemimpinan transformasional, kepemimpinan transaksional, orientasi pembelajaran dan creative self efficacy pada kreativitas mahasiswa. Hasil pengujian hipotesis menunjukkan keberadaaan pengaruh yang telah diduga dalam hipotesis. Pengaruh yang dihasilkan dari hasil olah data melaporkan apakah hipotesis yang telah diprediksi terdukung atau tidak terdukung. Berikut diuraikan pelaporan hasil pengujian hipotesis. Tabel 4 merupakan ringkasan pengujian hipotesis.

Tabel 4. Ringkasan Pengujian Hipotesis

\begin{tabular}{|c|c|c|c|}
\hline Hipotesis & Hubungan antar variabel & Hasil & Keterangan \\
\hline 1. & $\begin{array}{l}\text { Kepemimpinan transformasional } \\
\text { berpengaruh positif pada } \\
\text { kreativitas mahas iswa. }\end{array}$ & $\gamma=0.48, \mathrm{t}=2.68$ & Terdukung \\
\hline 2. & $\begin{array}{l}\text { Kepemimpinan } \\
\text { berpengaruh positif } \\
\text { kreativitas mahasiswa. }\end{array}$ & $\begin{array}{l}\gamma=0.013, \quad \mathrm{t}= \\
0.11,\end{array}$ & $\begin{array}{l}\text { Tidak } \\
\text { Terdukung }\end{array}$ \\
\hline 3. & 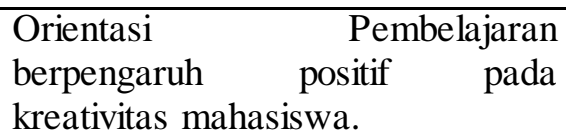 & $\begin{array}{l}\gamma=-0.34, \quad \mathrm{t}=- \\
2.04 .\end{array}$ & $\begin{array}{l}\text { Tidak } \\
\text { Terdukung }\end{array}$ \\
\hline 4. & $\begin{array}{l}\text { Creative self efficacy memediasi } \\
\text { pengaruh positif kepe mimpinan } \\
\text { transformasional pada } \\
\text { kreativitas mahas iswa. }\end{array}$ & $\gamma=0.35, \mathrm{t}=1.99$ & Terdukung \\
\hline 5. & $\begin{array}{l}\text { Creative self efficacy memediasi } \\
\text { pengaruh positif kepemimpinan } \\
\text { transaksional pada kreativitas } \\
\text { mahasiswa. }\end{array}$ & $\begin{array}{l}\gamma=-0.024, \mathrm{t}=- \\
0.21 .\end{array}$ & $\begin{array}{l}\text { Tidak } \\
\text { Terdukung }\end{array}$ \\
\hline 6. & $\begin{array}{lrr}\text { Creative self efficacy } & \text { memediasi } \\
\text { pengaruh } & \text { positif } & \text { orientasi } \\
\text { pembelajaran } & \text { pada } & \text { kreativitas } \\
\text { mahasiswa. } & & \\
\end{array}$ & $\begin{array}{l}\gamma=-0.49, \quad \mathrm{t}=\quad- \\
2.73\end{array}$ & $\begin{array}{l}\text { Tidak } \\
\text { Terdukung }\end{array}$ \\
\hline
\end{tabular}

Sumber : Hasil Penelitian, diolah (2018)

Selanjutnya dibahas bagaimana hasil penelitian memperluas dan meyakinkan hasil penelitian yang sebelumnya inconclusive. Berdasarkan hasil analisa persamaan struktural, hipotesis satu didukung. Kepemimpinan transformasional berpengaruh positif pada kreativitas mahasiswa. Hasil ini konsisten dengan penelitian yang dilakukan Gong et al. (2009), yang mana menjelaskan bahwa kepemimpinan transformasional berpengaruh positif pada kreativitas individu. Seorang pemimpin yang dalam hal ini melibatkan dosen yang mengajar dikelas kewirausahaan yang memiliki 
gaya kepemimpinan transformasional mempengaruhi mahasiswa untuk melakukan kreativitas pada tugas dan pekerjaan yang dilakukan.

Mahasiswa yang dididik dengan gaya kepemimpinan transformasional mendapatkan perhatian khusus terhadap kebutuhan dalam pencapaian dan pertumbuhan yang diharapkan. Dosen sebagai mentor atau pelatih bagi individu dengan menunjukkan dukungan terhadap pandangan dan inisiatif kreatif. Dosen menjadi sosok yang dikagumi, sehingga mahasiswa banyak belajar dari dosennya tentang ide-ide kreatif yang diperlukan di perkuliahan. Seorang pendidik memotivasi mahasiswa untuk memiliki sebuah visi dan menghasilkan kreativitas dan kinerja yang kreatif. Secara keseluruhan, seorang dosen yang memimpin secara transformasional mendorong otonomi mahasiswa untuk menggunakan pengetahuan dan pengalaman hebat untuk mengembangkan dirinya (Dvir et al., 2002).

Berdasarkan hasil analisis persamaan struktural, hipotesis dua tidak terdukung. Pengaruh gaya kepemimpinan transaksional dosen pada kreativitas mahasiswa tidak signifikan. Dosen menawarkan imbalan atau penghargaan serta pengawasan terhadap setiap kontribusi yang diberikan mahasiswa. Dosen dengan gaya transaksional cenderung tidak meningkatkan kreativitas mahasiswa. Bentuk penghargaan (contingent reward) yang diberikan oleh seorang dosen tidak cukup memotivasi untuk menciptakan ide-ide yang kreatif dan berguna. Dosen dianggap sebagai pengendali dan menyebabkan mahasiswa tidak termotivasi untuk melakukan hal-hal yang inovatif. Hasil temuan ini mengarisbawahi bahwa kepemimpinan transaksional tidak selalu memiliki pengaruh yang negatif bagi para pengikutnya, tapi memberikan tekanan yang menghambat ide-ide kreatif dengan adanya pengawasan dan bentuk-bentuk penghargaan yang kurang jelas dideskripsikan.

Hasil analisa persamaan struktural menjelaskan bahwa hipotesis tiga tidak terdukung. Orientasi pembelajaran ditemukan berpengaruh negatif pada kreativitas mahasiswa. Hasil temuan ini tidak konsisten dengan studi yang dilakukan oleh Gong et al. (2009) yang menjelaskan bahwa orientasi pembelajaran berpengaruh positif signifikan pada kreativitas individu. Mahasiswa bereaksi ketika diberikan tugas dan pekerjaan.. Orientasi yang berbeda akan mendorong respon pola perilaku individu yang berbeda. Individu yang memiliki orientasi pembelajaran mencari tantangan yang menawarkan kesempatan untuk belajar. Berdasarkan hal tersebut, peneliti menduga konsep orientasi pembelajaran tidak sesuai, dikarenakan karakteristik individu dari masing-masing responden berbeda- beda, faktor tujuan masing-masing individu diduga mempengaruhi orientasi pembelajaran individu.

Hasil analisis persamaan struktural menunjukkan bahwa kepemimpinan transformasional berpengaruh positif signifikan pada creative self efficay dan creative self efficacy berpengaruh positif pada kreativitas Mahasiswa. Hal ini menunjukkan bahwa creative self efficacy memediasi hubungan anteseden dengan kreativitas Mahasiswa. Dosen yang memiliki kepemimpinan yang transformasional merupakan suatu kendaraan yang potensial untuk membentuk creative self-efficacy. Individu yang memiliki creative self-efficacy memiliki keyakinan terhadap kemampuannya untuk memproduksi hasil yang kreatif (Tierney dan Farmer, 2002). Dosen memberikan vicarious learning untuk menghasilkan kreativitas pada mahasiswa. Dukungan dan bimbingan dosen dapat membujuk (verbal persuasion) serta membantu individu agar 
mereka memiliki keyakinan akan kemampuan mereka menghasilkan sesuatu yang kreatif dengan pengalaman langsung (enactive mastery). Rasa empati, apresiasi, perhatian yang diberikan dosen, membuat mahasiswa mengalami physiological arousal yang membentuk keyakinan untuk melakukan sesuatu yang kreatif. Hasil temuan ini memperkuat studi yang dilakukan Gong et al. (2009).

Kepemimpinan transaksional seperti yang dibahas sebelumnya tidak berpengaruh signifikan pada kreativitas mahasiswa. Kepemimpinan transaksional tidak berpengaruh signifikan pada creative self efficacy. Individu yang memiliki kepemimpinan dengan gaya transaksional cenderung tidak membentuk keyakinan mahasiswa akan kemampuannya untuk menghasilkan hal-hal yang kreatif. Hasil analisa persamaan struktural menunjukkan bahwa orientasi pembelajaran berpengaruh negatif pada kreativitas mahasiswa, akan tetapi hasil evaluasi persamaan struktural menunjukkan bahwa orientasi pembelajaran ditemukan berpengaruh signifikan pada creative self efficacy.Dalam pembahasan hipotesis tiga, peneliti menguraikan dugaan pengaruh negatif terjadi pada hubungan orientasi pembelajaran dan kreativitas dikarenakan konsep orientasi pembelajaran yang dimiliki masing-masing individu berbeda dengan tujuan masing-masing responden dalam mengerjakan tugas dan pekerjaan sebagai mahasiswa. Seorang akan termotivasi untuk belajar dengan tugastugas yang lebih menantang, sehingga ia memiliki keyakinan untuk menyelesaikan pekerjaan dengan cara yang baik dan kreatif.

\section{KESIMPULAN DAN SARAN Kesimpulan}

Kepemimpinan transformasional berpengaruh positif pada kreativitas mahasiswa. Mahasiswa yang diasuh dan didik dengan gaya kepemimpinan transformasional akan menghasilkan kreativitas pada tugas dan pekerjaannya. Kepemimpinan transformasional memberikan stimulasi intelektual, pertimbangan individual, pengaruh ideal dan motivasi inspirasional pada individu, sehingga individu tersebut termotivasi untuk menciptakan ide-ide baru dan berguna serta menghasilkan kreativitas. Creative self-efficacy memediasi pengaruh positif kepemimpinan transformasional pada kreativitas mahasiswa. Kepemimpinan transformasional akan membentuk creative self-efficacy mahasiswa. Dengan mempertahankan creative selfefficacy, seseorang tersebut dapat menghasilkan kreativitas. Kepemimpinan transformasional membentuk creative self-efficacy melalui vicarious learning, verbal persuasion, enactive mastery dan physiological arousal. Mahasiswa akan memiliki keyakinan akan kemampuan untuk melakukan hal-hal yang kreatif dengan dukungan dan bimbingan dari dosen dengan gaya kepemimpinan transformasional.

Kepemimpinan transaksional tidak berpengaruh signifikan pada kreativitas mahasiswa. Mahasiswa yang diasuh dan didik dengan gaya kepemimpinan transaksional belum dapat menghasilkan kreativitas pada tugas dan pekerjaannya. Peran pemimpin transaksional dianggap sebagai pengendali, yang menghambat ruang gerak individu untuk menghasilkan ide-ide kreatif. Orientasi pembelajaran berpengaruh negatif pada kreativitas mahasiswa. Konsep orientasi pembelajaran harus disesuaikan dengan tujuan individu dalam mencapai target. Seseorang akan memelihara orientasi 
pembelajarannya, ketika ia dihadapkan pada tugas atau pekerjaan yang menantang, sehingga ia berfokus untuk mengakuisisi pengetahuan yang dimilikinya.

Creative self-efficacy tidak memediasi pengaruh kepemimpinan transaksional dan orientasi pembelajaran pada kreativitas mahasiswa. Kepemimpinan transaksional tidak membentuk creative self efficacy, karena seorang pemimpin transaksional tidak mengikutsertakan dalam mengambil keputusan, menghambat ruang gerak dengan adanya standar yang telah ditetapkan. Individu yang diasuh dan dididik oleh pemimpinan transaksional tidak mampu mempertahankan creative self-efficacy dalam dirinya, sehingga ia tidak dapat menghasilkan hal-hal yang kreatif dalam menyelesaikan pekerjaannya.Konsep orientasi pembelajaran ditemukan memelihara creative self-efficacy, tapi tidak dapat menghasilkan kreativitas tanpa adanya pengaturan pekerjaan yang lebih menantang. Konsep creative self-efficacy mungkin akan memediasi pengaruh positif orientasi pembelajaran pada kreativitas, jika pengaturan pekerjaan yang dilakukan adalah suatu pekerjaan yang membutuhkan tingkat pengetahuan yang lebih tinggi.

\section{Saran}

Penelitian ini menggunakan data laporan diri (self-report), sehingga kemungkinan untuk mengalami common method bias terjadi. Skala pengukuran merupakan salah satu faktor yang dapat mempengaruhi terjadinya common method bias. Pada penelitian ini, pengukuran menggunakan satu jenis skala pengukuran yaitu, skala likert 1 (sangat tidak setuju) sampai dengan 5 (sangat setuju). Hal ini dapat memungkinkan responden untuk tidak menjawab kuesioner dengan baik dan akurat. Pada penelitian mendatang, diharapkan menggunakan skala pengukuran yang berbeda untuk masing-masing konstruk yang digunakan dalam penelitian.Penelitian ini menggunakan data cross-sectional sehingga tidak mengungkapkan hubungan kausal. Pada penelitian mendatang desain longitudinal atau eksperimen diperlukan untuk membangun hubungan kausalitas.Penelitian ini hanya berfokus pada penelitian anteseden kreativitas mahasiswa dan mekanisme psikologis yang menghubungkan anteseden pada kreativitas mahasiswa. Penelitian pada masa yang mendatang diharapkan menguji pengaruh kreativitas pada kinerja pekerjaan, untuk mengeneralisasi manfaat kreativitas dalam organisasi.Sampling dalam penelitian ini tidak random sehingga generalisasi dilakukan secara hati-hati. Pengujian hipotesis pada penelitian ini menggunakan mahasiswa yang mengambil mata kuliah kewirausahaan di Program studi Manajemen Fakultas Ekonomi Universitas HKBP Nommensen Medan. Pada penelitian mendatang, diharapkan mereplikasi hasil penelitian ini di pengaturan organisasi dan jenis pekerjaan yang berbeda.

\section{DAFTAR PUSTAKA}

Amabile, T. M. 1988. A Model of Creativity and Innovation in Organizations. Research in Organizational Behavior. 10: 123-167

Amabile, T. M., Conti, R., Coon, H., Lazenby, J., \& Herron, M. 1996. Assesing the work environment for creativity during downsizing. Academey of Management Journal, 42:630-640. 
Avolio, B. J., Bass, B. M., \& Jung, D. I. 1999. Re-Examining The Components of Transformational and Transactional Leadership Using The Multifactor Leadership Questionaire. Journal of Occupational and Organizational Psychology, 72: 441-462.

Bandura, A. 1977. Self-Efficacy: Toward A Unifying Theory of Behavioral Change. Psychological Review, 84: 191-215.

Barron, R. M., \& Kenny, D. A. 1986. The Moderator-Mediating Variable Distinction In Social Psychological Research: Conceptual, Strategic, And Statistical Consideration. Journal of Personality and Social Psychology, 51: 1173-1182.

Bass, B. M. 1999. Two Decades of Research and Development in Transformational Leadership. European Journal of Work and Organizational Psychology, 8: 9-32.

Bass, B. M., Avolio, B. J., Jung, D. I., \& Berson, Y. 2003. Predicting Unit Perfomance by Assesing Transformasional and Transactional Leadership. Journal of Applied Psychology, 88: 207-218.

Boerner, S., Eisenbeiss, S. A., \& Griesse, D. 2007. Follower behavior and organizational performance: The impact of transformational leaders. Journal of Leadership \& Organizational Studies, 13:15-26.

Dvir, T., Eden, D., Avolio. J. B., \& Shamir, B. 2002. Impact of transformational leadership on follower development and perfomance: A field experiment. Academy of Management Journal, 45: 735-744.

Dweck, C. S., \& Leggett, E. L. 1988. A social-cognitive approach to motivation and personality. PsychologicalReview, 95: 256-273.

Eisenberger, R., \& Rhoades, L. 2001. Incremental effects of reward on creativity. Journal of Personality and Social psychology, 81: 728-741.

Elliot, E. S., \& Church. M. A. 1997. A hierarchical model of approach and avoidance achievement motivation. Journal of Personality and Social Psychology, 72: 218232.

Ghafoor, A., Qureshi, T. M., Azeemi, H. R., \& Hijazi, S. T. 2011. Mediating role of self-efficacy. African Journal of Business Management, 5:11093-11103.

Gong, Y., Huang, JC., \& Farh, JL. 2009. Employee learning orientation, transformational leadership, and employee creativity: The mediating role of employee self-efficacy. Academy of Management Journal, 52: 765-778.

Hair, Jr, J.F; W.C. Black; B.J. Babin; R.E. Anderson; and R.L. Tatham (2006), Multivariate Data Analysis, $6^{\text {th }}$ ed. Upper Saddle River, NJ: Pearson Education.

Liu, W., Lepak, P. D., Takeuchi, R. \& Jr, S. P. H. 2003. Matching leadership styles with employment modes: strategic human resources management perspective. Human Resource Management Review, 13: 127-152.

Malau, R. A. 2012. Pengaruh Kepemimpinan Transformasional, Kepemimpinan Transaksional, dan Orientasi Pembelajaran pada Kreativitas Karyawan Dengan Variabel Pemediasi Creative Self Efficacy.Universitas Gadjah Mada. Yogyakarta

Neuman, W. L. 2006. Social Research Methods: Qualitative and Quantitative Approaches. 6th ed., Pearson Education.

Nonaka, I., \& Takeuchi, H. 1995. The knowledge-creating company. Oxford University Press-New York. 
Oldham, G. R., \& Cummings, A. 1996. Employee creativity: Personal and contextual factors at work. Academy of Management Journal, 39: 607-634.

Pieterse, N.A., Knippenberg, V. D., Schippers, M., \& Stam, D. 2010. Transformasional and transactional leadership and innovative behaviour: The moderating role of

Shalley, C. E. 1991. Effects of productivity goals, creativity goals and personal discretion on individual creativity. Journal of Applied Psychology, 76: 179-185.

Shalley, C. E. 1995. Effects of coaction, expected evaluation, and goal setting on creativity and productivity. Academy of Management Journal, 38: 483-503.

Shalley, C. E., Gilson, L. L., \& Blum, T. C. 2000. Matching creativity requirement and the work environment: Effect on satisfaction and intention to leave. Academy of Management Journal, 43: 215-223.

Shalley, C. E., Zhou, J., \& Oldham, R. G. 2004. The effects of personal and contextual characteristics on creativity: where should we go from here?. Journal of Management, 30: 933-958.

Shin, S. J., \& Zhou, J. 2003. Transformasional leadership, conservation, and creativity: Evidence from Korea. Academy of Management Journal, 46: 703-714.

Tierney, P., \& Farmer, S.M. 2002. Creativity self-efficacy: Its potential antecedents and realationship to creative perfomance. Academy of management Journal, 45: 1137-1148

Zhou, J., \& Shalley, C. E. 2003. Research on employee creativity: A critical review and direction for future research. Research in Personel and Human Resource Management, 165-217 